\title{
Constructing a Path to Improving Teaching Quality in Higher Applied Education
}

\author{
Gui-hua YU* \\ Basic teaching department \\ Wenzhou Business College \\ Wenzhou, China \\ 1037237047@qq.com
}

\author{
Shi-jun ZHANG \\ School of foreign languages and foreign trade \\ Wenzhou Business College \\ Wenzhou, China \\ zsj990901@163.com
}

\begin{abstract}
The purpose of the study is to improve the teaching quality of higher occupation education, the traditional teaching mode in higher vocational colleges is difficult to adapt to the reality of development, and must restore the curriculum standard. Based on the work, to cultivate high-quality skilled talents of international trade documents operation, must actively attempt to reform the teaching. The teaching system of "teaching, learning and doing" is constructed with the example of the international business document course with the field investigation method, expert interview method and experimental method. The research results show that the course system has improved the quality of teaching and aroused the students' interest in learning. Taking the business process as the main line, building a curriculum system with "teaching, learning and doing" is the innovation of the paper.
\end{abstract}

Keywords-higher vocational education; curriculum planning; task orientation; safeguard measures

\section{INTRODUCTION}

The higher vocational education is to train highly skilled and applied talents. They directly face the actual work position and do a line of business operation. At present, almost all of the major foreign trade vocational colleges have opened related courses for foreign trade, but according to the survey, most vocational colleges' foreign trade documents curriculum deviates from their actual job requirements, for example, many vocational students have studied in school for 3 years, but have never seen or filled in a real document, many students do not know what they have learned, nor do they know where to use it ${ }^{[1]}$. Students have studied this course of documents, but they still do not understand the business process of foreign trade documents and the special notices of many documents, when confronted with practical problems, they are often helpless, and the trained students cannot meet the needs of the actual jobs of the foreign trade enterprises.

Through the investigation on students of higher vocational colleges, for the students, there are many learning difficulties in this course, they express too many types of foreign trade documents, the lack of learning patience; fill in the specification documents too many contents cumbersome; their English foundation is weak, the lack of confidence in the full expression of English learning all kinds of foreign trade documents. At the same time, they also recognize the

The Project of Zhejiang Educational Science Planning (2018SCG171)" Research on the continuous improvement mechanism of the quality of newly established undergraduate universities based on the third party evaluation". practicality of this course, in the practical work in the future is more useful, also expressed the study expectation in the course, hope the teacher to contact the actual work. Therefore, it is necessary to introduce new teaching models, reform traditional teaching methods innovate teaching methods and teaching methods, help students overcome psychological barriers, stimulate students' interest in learning.

The work process oriented curriculum concept and curriculum model, also known as the typical work task analysis method, was first proposed by the Institute of technology and vocational education of the University of Bremen in Germany in 1990s. It is based on the integration of modern professional work and is based on the systematic design of the work process. The course design method based on the working process is the curriculum development method advocated by the higher vocational education in China. In 2004, the Ministry of education, the Ministry of labor and Social Security jointly issued the training program for training the skilled personnel in Vocational Colleges and universities, and put forward the course "the course development should be related to the working process in a definite degree." Design concept. The selection and sorting of the course content should be based on the working process in the guidance scheme, but there is no guidance for the course based teaching model based on the working process ${ }^{[2]}$.

The "working process" is a complete work program to complete a task in the enterprise, in the working process of meaning: an occupation can become an occupation, because of its special work process, namely in the work mode, method, content, organization and tools of history the development has its own unique. We believe that teaching situation is the key element of curriculum design based on work process, because the learning content of higher vocational education is closely related to the professional situation of practical work. Therefore, the transformation of the content of the traditional international business documents into a number of teaching scenarios is the essence of curriculum design based on the working process.

\section{CURRICUlum DESIGN THOUGHT BASED ON WORKING PROCESS}

First, the social industry experts locate the actual working process of the work position of the course, determine the specific content of the work, then decompose the work content, 
transform it into several work items, give the work project specific task and follow the work task. To determine the ability of the professional post, including three aspects: social ability, method ability and professional ability. The work task and the corresponding professional ability are integrated, the relevant actual working process of the project table, provided to the school professional teaching system to carry out curriculum teaching design. According to industry experts to provide professional teachers work and occupation ability coupled, re integration of curriculum content, according to the work process is divided into several relatively independent content modules, to match the corresponding tasks. The project is based on task decomposition in the working process of the course design, teaching content design into one or more specific tasks, let the students to complete specific tasks, grasp the teaching content, to reach the goal of teaching.

Then the teaching scenario is designed according to the reconstruction of the task items involved in the course. The design of teaching situation is to provide a complete and real problem background for the students. It is the reappearance of the specific tasks on the actual work position of the enterprise, which is generally embodied in the form of specific tasks. In the course of completing the teaching situation, students need to master two kinds of knowledge, one is the basic professional ability of the post, it is the knowledge of the concept in the course, that is, the problem of explaining "what is"; the two is the professional skills of the post, that is, the operational knowledge in the course, and it is the problem to solve "how to do". The focus of curriculum design and course teaching in vocational education should be focused on the learning and training of operational knowledge to help students learn and master the knowledge, experience and skills that are included in the actual work process.

Finally, in each teaching situation, according to the sequence of the work process, find out the key skills to support the task, through the follow-up intensive teaching, learning, and doing integrated training, to achieve the actual employment jobs to cultivate professional skills for the purpose of teaching objectives. (The specific course design process is shown in Fig. 1).

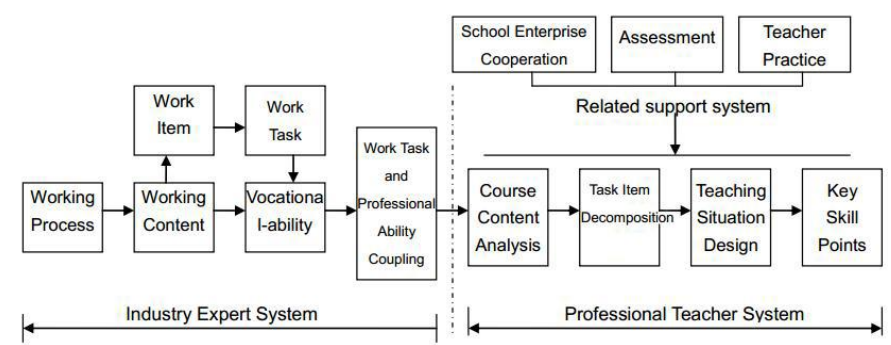

Fig. 1. Curriculum Design Process based on Work Process

\section{OPTIMIZATION OF TEACHING DESIGN OF INTERNATIONAL BUSINESS DOCUMENTS}

\section{A. Integration of Curriculum Content}

The international business document is a major course of international trade and trade specialty. Through this course, students will be familiar with the whole operation process of foreign trade, and the English documents of foreign trade involved in every link of foreign trade business can be skillfully made up. It runs through the whole process of foreign trade, procurement, delivery, settlement, cancellation, and tax refund. It has a large amount of work, time and wide coverage. The work of the whole process needs cooperation and cooperation between various departments of foreign trade enterprises, and it also must be produced with banks, commodity inspection, customs, insurance, transportation and other related departments. Every aspect of life is interrelated and interrelated. The documents involved in this course include commercial invoices, transport documents, insurance policies, certificate of origin, certificate of inspection, packaging documents and other documents, such $\mathrm{as}^{[3]}$. According to the actual working process of international trade, the course content is redesigned, the order and content of the original textbook are broken, such as the general task of "a company's transaction process of a certain company" as the main line, and the teaching content is reintegrated in accordance with the documentary work of the actual international trade process. The content of international business documents is divided into modules. According to the process of foreign trade documents, the contents of the course are integrated into five modules: contract management, letter of credit, import and export collection and payment, transportation and insurance, and management of documents. The teaching contents are displayed through modules.

\section{B. Teaching Situation Design}

After the above work process decomposition and knowledge preparation based on the work process, teachers began to collect real cases of foreign trade enterprises and carefully design teaching scenarios. Through the task of working with the students, the students can guide the students to conduct the operation and training of the work tasks under the various real business backgrounds, and integrate teaching, learning and doing. Each teacher first introduces a task to give the real business information involved in the task. In order to make the students complete the task better, the teachers first introduce the basic knowledge needed by the work task, and then let the students try to carry out the business operation according to the assigned tasks and instruct by the teachers. When necessary, the teacher can analyze the operation of the students and carry out the demonstration of the project activities; finally, the students can correct the operation errors and the skillful operation steps according to the demonstration operation of the teachers, and continue to complete the work independently. For students who have never met with foreign trade, it is difficult for them to feel the real foreign trade practice from the abstract text of the book ${ }^{[4]}$. Through the above teaching situation, the students are no longer the only "listeners" to listen to. They are incarnated as the salesman and the producer of the foreign trade company. The classroom also becomes "xx company", "Customs", "ship company". Their mission is no longer to listen to lectures or take notes, but to negotiate a foreign trade business or to produce a document. In this way, students' participation, initiative and enthusiasm can be mobilized, so as to improve the teaching effect of "international business documents". (See table 1). 
TABLE I. COURSE CONTENT, WORK TASK, AND STUDENT OPERATION CORRESPONDING TABLE

\begin{tabular}{|c|c|c|c|c|}
\hline $\begin{array}{l}\text { Content } \\
\text { Module }\end{array}$ & $\begin{array}{c}\text { Work task } \\
\text { decomposition }\end{array}$ & $\begin{array}{c}\begin{array}{c}\text { Assignment of students' work } \\
\text { tasks }\end{array} \\
\end{array}$ & Key skill points & $\begin{array}{l}\text { Examination } \\
\text { Voucher }\end{array}$ \\
\hline \multirow[t]{2}{*}{$\begin{array}{c}\text { Contract } \\
\text { Administration }\end{array}$} & $\begin{array}{l}\text { Transactions and } \\
\text { consultations }\end{array}$ & $\begin{array}{l}\text { Use the knowledge of foreign } \\
\text { trade correspondence to consult } \\
\text { with foreign businessmen; Use } \\
\text { consultation related knowledge to } \\
\text { resolve disputes in actual work }\end{array}$ & $\begin{array}{l}\text { Correspondence } \\
\text { writing, negotiation, } \\
\text { offer, acceptance }\end{array}$ & $\begin{array}{l}\text { Counter-offer } \\
\text { record }\end{array}$ \\
\hline & $\begin{array}{l}\text { Conclude } \\
\text { contract }\end{array}$ & $\begin{array}{l}\text { Drafting trade contracts with the } \\
\text { results of consultations }\end{array}$ & Contract format & $\begin{array}{l}\text { Contract } \\
\text { pattern }\end{array}$ \\
\hline \multirow[b]{2}{*}{ Letter of credit } & Letter of credit & $\begin{array}{l}\text { Filling in an application form in } \\
\text { accordance with the import } \\
\text { contract }\end{array}$ & Application form & $\begin{array}{l}\text { Application for } \\
\text { a letter of } \\
\text { credit }\end{array}$ \\
\hline & $\mathrm{L} / \mathrm{C}$ audit & $\begin{array}{l}\text { Read and understand the contents } \\
\text { of the letter of credit; Audit of } \\
\text { letters of credit in accordance } \\
\text { with the contents of the contract }\end{array}$ & $\begin{array}{l}\text { Letter of credit } \\
\text { format and letter of } \\
\text { credit }\end{array}$ & $\begin{array}{l}\text { The trial } \\
\text { record }\end{array}$ \\
\hline \multirow{2}{*}{$\begin{array}{l}\text { Receipts and } \\
\text { payments }\end{array}$} & $\begin{array}{l}\text { Prepare export } \\
\text { documents }\end{array}$ & $\begin{array}{l}\text { Export declaration form, invoice, } \\
\text { packing list, certificate of origin, } \\
\text { transport bill, bill of exchange, } \\
\text { packing list, export license, etc. }\end{array}$ & $\begin{array}{l}\text { Fill in all kinds of } \\
\text { documents and } \\
\text { format requirements }\end{array}$ & $\begin{array}{l}\text { Full set of } \\
\text { documents }\end{array}$ \\
\hline & $\begin{array}{l}\text { Fill in the import } \\
\text { documents }\end{array}$ & $\begin{array}{l}\text { Import customs declaration form, } \\
\text { transport bill, inspection form, } \\
\text { import license, etc. }\end{array}$ & $\begin{array}{l}\begin{array}{l}\text { Fill in all kinds of } \\
\text { documents and } \\
\text { format requirements }\end{array} \\
\end{array}$ & $\begin{array}{l}\text { Full set of } \\
\text { documents }\end{array}$ \\
\hline \multirow{3}{*}{$\begin{array}{l}\text { Transportation } \\
\text { and insurance }\end{array}$} & $\begin{array}{l}\text { Charter and } \\
\text { Booking }\end{array}$ & Fill in the letter of entrustment & Booking form & Shipping note \\
\hline & Shipment & $\begin{array}{l}\text { Fill in the shipping bill of bill of } \\
\text { lading }\end{array}$ & Transport form & Bill of loading \\
\hline & Insurance & $\begin{array}{l}\text { Fill out the policy sheet and the } \\
\text { insurance policy }\end{array}$ & $\begin{array}{l}\text { Insurance policy } \\
\text { form }\end{array}$ & $\begin{array}{l}\text { Insurance } \\
\text { policy }\end{array}$ \\
\hline \multirow[b]{2}{*}{$\begin{array}{l}\text { Documents } \\
\text { Administration }\end{array}$} & $\begin{array}{l}\text { Documents } \\
\text { Audit }\end{array}$ & $\begin{array}{l}\text { Audit of various documents } \\
\text { according to contract and } \mathrm{L} / \mathrm{C}\end{array}$ & $\begin{array}{l}\text { Audit requirements: } \\
\text { documents }\end{array}$ & Audit record \\
\hline & $\begin{array}{l}\text { Documents } \\
\text { Delivery }\end{array}$ & $\begin{array}{l}\text { The number and arrangement of } \\
\text { all kinds of documents, and form } \\
\text { a "package" document }\end{array}$ & $\begin{array}{l}\text { The complete } \\
\text { documents; the order } \\
\text { of the documents }\end{array}$ & $\begin{array}{l}\text { Delivery } \\
\text { records }\end{array}$ \\
\hline
\end{tabular}

\section{Evaluate, Feedback and Communicate and Reinforce Key Skills}

Through the design of teaching scenarios, students basically complete the tasks assigned, and eventually produce the results of their work as a credential for their assessment. After the task is completed, the teacher first makes an overall evaluation of the work done, and gives the corresponding examination results according to its working process and task results. During this process, students were asked to answer questions in the process of working tasks, and teachers were given answers. Then, the teachers then systematically comb the relevant practical knowledge and theoretical knowledge of the task link, so that the students can form a more complete knowledge system. Finally, the teacher emphasized the key skill points of the task to the students as a follow-up to the intensive training in the training room in the school or the focus of the practice at the outside school training base. In this way, through mutual exchanges between teachers and students, mutual strengthening has further deepened the mastery of international business documents and its proficiency in application.

\section{RELATED SUPPORTING MEASURES}

\section{A. Protection of external conditions}

The implementation of the course design scheme based on the working process depends on the guarantee of certain external conditions. It is necessary to establish the corresponding training room in the school and the practice training base outside the school, so that the students will have the opportunity to practice the key skills based on the work process in the real position of the enterprise. To meet this requirement, enterprises need to have a high participation in school enterprise cooperation. Besides, higher vocational colleges should establish an expert information exchange system for off campus industries, so as to establish a curriculum oriented system based on the working process. All these require the government's policy support to ensure the effective operation of school enterprise cooperation.

\section{B. The improvement of teachers' professional practice ability}

Based on the optimization of the course teaching, the design of the teaching situation is the key and key point. This means that teachers must be able to develop teaching based on the task oriented teaching situation according to the professional ability training and the goal of the students' personality needs ${ }^{[5]}$. Teachers who undertake the teaching of international business documents must have rich practical experience and must go deep into the relevant research of enterprises. Therefore, the higher vocational colleges should create the opportunities for professional teachers to go to the enterprises to hang up the job, so that they can accumulate relevant experience of international business documents and train the "Double Teachers" teaching staff based on the needs of the work process teaching.

\section{Reforming curriculum assessment methods}

Changing the single theory closed book examination method, adopting the theory of testing, usual performance, practical operation of the diversified evaluation system ${ }^{[6]}$. For the actual operation part, in the course design based on the working process, the corresponding assessment results are given according to the attitude and effect of the work tasks completed by the students. In the specific assessment program, the attendance performance accounted for $10 \%$ of the total achievement, the quality and quantity of the homework completed $10 \%$, the basic theoretical knowledge comprehensive test accounted for $20 \%$, the middle school students' completion process evaluation and the achievement evaluation of the assigned tasks accounted for $10 \%$ and $30 \%$ respectively, and the final course design scheme after the end of the course accounted for $20 \%$. Teachers can make appropriate adjustments according to the overall quality of students and the overall layout of the courses.

\section{CONCLUSION}

After careful investigation, symposium and teaching seminars, put forward the course design based on working process, first by the social position of industry experts is work on the course of the actual work process, then the content of the work is decomposed into a number of work items, and then according to the curriculum related project, design the teaching scene, finally in every teaching situation, according to the work process to carry out the order, find out the support of the mission critical skills, through the subsequent strengthening of teaching, learning and doing integration training, finally construct the curriculum system. The implementation of the curriculum system has indeed improved the teaching effect, and the research results provide a reference value for the reform of other related courses. 


\section{REFERENCES}

[1] Y. F. Cui, "Post requirements and teaching strategies for international business documents in Higher Vocational Colleges," Journal of Guangdong Youth Cadre College. Guangdong, vol. 13, pp. 86-89, August 2008. (In Chinese).

[2] L. Yang, "Design and implementation of curriculum program the working process," Journal of Tianjin Institute of Finance. Tianjin, vol. 18, pp. 63-64, December 2009. (In Chinese).

[3] P. Shen, "Teaching practice of "foreign trade document practice" course," Journal of Shazhou Vocational College of Engineering, Guangdong, vol. 24, pp. 52-55, April 2008. (In Chinese).

[4] L. Cui, "Three dimensional teaching model reform of international business documents course," Journal of Xiamen Educational College. Xiamen, vol. 10, pp. 40-43, February 2009. (In Chinese).
[5] L. Yang, "Design and implementation of curriculum plan based on work process," Journal of Tianjin Institute of Finance. Tianjin, vol. 17, pp. 6364, February 2009. (In Chinese).

[6] W. Tan, "Constructing new curriculum framework of foreign trade document practice with CDIO education mode," Logistics purchasing and research. Beijing, vol. 14, pp. 72-75, October 2009. (In Chinese).

[7] V. Dirk, A. C. Marten, "What is Stakeholder Democracy ? Perspectives and Issues," Business Ethics European Review. London, vol. 48, pp. 568-579, January 2005.

[8] A. Patrick, "The New Market-state and Education," Journal of Education Policy. New York, Vol. 19, pp. 1402-1423, July 2004.

Notes: The Project of Zhejiang Educational Science Planning (2018SCG171)"Research on the continuous improvement mechanism of the quality of newly established undergraduate universities based on the third party evaluation". 